\title{
PERLUNYA BELAJAR MATA KULIAH ALJABAR ABSTRAK BAGI MAHASISWA CALON GURU MATEMATIKA
}

\author{
Melda Jaya Saragih \\ Universitas Pelita Harapan, Jl. M.H. Thamrin Boulevard 1100, Tangerang 15811, Banten \\ melda.saragih@uph.edu
}

\begin{abstract}
The teacher's perspective on mathematics will influence the way their teaches. Prospective teachers often assume that learning advanced courses at universities is not useful for their teaching later in school. The purpose of this study is to explore what competencies are developed in the prospective teacher students during abstract algebra lectures and how the prospective students understand the importance of learning abstract algebra. The method used in this study is a qualitative descriptive method. Students are asked to observe cognitive development in themselves from every abstract algebra learning experience. Data is collected through questionnaires, reflections and student interviews. The research subjects were 90 students who took the Abstract algebra course. The results of the study were obtained 1) In general, students' mathematical competencies increasingly develop after abstract algebra lectures through student learning experience, 2) Students agree that abstract algebra courses are relevant for them as educators at the school level because learning abstract algebra enables students to develop competencies and concepts in mathematics. This research provides an overview of the need to learn complex mathematical concepts for a prospective teacher.
\end{abstract}

Keywords: Abstract Algebra, Prospective teacher, Relevance

\begin{abstract}
Abstrak
Cara pandang guru terhadap matematika akan berpengaruh terhadap cara pengajarannya. Calon guru sering menganggap bahwa belajar mata kuliah lanjutan pada perguruan tinggi tidak berguna bagi pengajaran mereka nantinya di sekolah. Tujuan dari penelitian ini adalah untuk menggali tentang kompetensi apa saja yang dikembangkan dalam diri mahasiswa calon guru selama perkuliahan aljabar abstrak serta bagaimana pemahaman mahasiswa calon guru terhadap pentingnya belajar aljabar abstrak. Metode yang digunakan dalam penelitian ini adalah metode deskriptif kualitatif. Mahasiswa diminta untuk mengamati perkembangan kognitif dalam diri mereka dari setiap pengalaman belajar aljabar abstrak. Data dikumpulkan melalui angket, refleksi dan wawancara mahasiswa. Subjek penelitian sebanyak 90 mahasiswa yang mengikuti mata kuliah aljabar Abstrak. Hasil penelitian diperoleh 1) Secara umum kompetensi matematik mahasiswa semakin berkembang setelah perkuliahan aljabar abstrak melalui pengalaman belajar mahasiswa, 2) Mahasiswa setuju bahwa mata kuliah aljabar abstrak relevan bagi mereka sebagai seorang pendidik di tingkat sekolah dikarenakan dengan belajar aljabar abstrak membuat mahasiswa dapat mengembangkan kompetensi dan konsep-konsep matematika. Penelitian ini memberikan gambaran perlunya belajar konsep matematika yang kompleks bagi seorang calon guru.
\end{abstract}

Kata kunci: Aljabar Abstrak, Calon guru, Relevansi

Berdasarkan Undang-Undang Nomor 14 Tahun 2005 tentang Guru dan Dosen, dibutuhkan 4 Kompetensi profesi seorang guru yaitu kompetensi pedagogik, kompetensi kepribadian, kompetensi sosial, dan kompetensi profesional. Kompetensi profesional seorang guru meliputi: penguasaan materi, struktur, konsep, dan pola pikir keilmuan, yang mendukung mata pelajaran yang diampu (Depdiknas, 2005). Menjadi seorang guru penting sekali menguasai materi, struktur, konsep dan pola pikir matematika. Seorang guru bidang studi diharapkan linear dengan bidang ilmu yang dipelajari selama perkuliahan. Hal ini untuk mengakomodir kompetensi professional seorang guru. Guru matematika perlu terus menerus meningkatkan kompetensi profesionalnya ditengah masih banyaknya siswa yang masih belum menyukai matematika. Guru yang memiliki kompetensi professional yang 
sangat baik akan menjadi daya tarik bagi siswa belajar untuk serius karena guru akan memberi penjelasan dan pemaparan yang memadai (Naim, 2011). Perlu mempersiapkan guru matematika dengan kompetensi matematika yang baik, melalui mata kuliah matematika yang sudah ditawarkan di dalam perkuliahan. Salah satu mata kuliah matematika yang membutuhkan kemampuan kompleks selama perkuliahan di prodi Pendidikan matematika adalah mata kuliah aljabar abstrak.

Bagaimana guru matematika mengajarkan setiap bagian dari materi matematika dipengaruhi oleh bagaimana pandangan guru terhadap matematika tersebut (Reys, 2014). Jika guru mengalami sendiri matematika, maka dia akan mengarahkan siswa untuk mengalami matematika itu selama pembelajarannya. Keyakinan guru matematika akan matematika itu sendiri, sangat berpengaruh terhadap pengajarannya. Dalam hal ini, seorang guru matematika bisa saja menganggap sebagian atau keseluruhan materi matematika adalah sulit, maka otomatis guru akan mentransfer kesulitan itu dalam pengajarannnya. Jika guru menganggap matematika adalah alat untuk mengembangkan kemampuan berpikir setiap orang yang mempelajarinya, maka dia akan mendesain kegiatan pembelajaran sesuai dengan keyakinannya tersebut. Keyakinan seorang guru terhadap matematika, mengambil bagian besar bagaimana dia akan menyusun kurikulum dalam pembelajarannya. Sehingga hal ini perlu menjadi perhatian selama mahasiswa menempuh pendidikan di universitas meskipun kompetensi matematika ini sangat kompleks. Keberhasilan seorang anak didik dipengaruhi oleh pribadi, kemampuan guru yang inspiratif dalam membuat suasana pembelajaran serta usaha dari dalam diri anak. Minat belajar siswa terhadap suatu subjek materi yang disampaikan guru merupakan gambaran kompetensi profesional guru (Naim, 2011). Sehingga perlu ditanamkan setiap peserta didik yang belajar matematika mengalami sendiri matematika dan bagaimana matematika melatih cara berpikir mereka. Dengan melihat dampak seorang guru terhadap siswa dalam belajar matematika, maka perlu dipersiapkan calon guru matematika dengan kompetensi matematika yang memadai sejak dari tingkat universitas. Selain itu sikap mahasiswa terhadap matematika dan kesulitan dalam belajar matematika perlu diperhatikan agar mahasiswa dapat mengalami proses berpikir yang maksimal selama perkuliahan.

Belajar adalah suatu proses perubahan dalam diri manusia, dan perubahan tersebut ditunjukkan dalam bentuk peningkatan kualitas dan kuantitas tingkah laku seperti peningkatan kecakapan, pengetahuan, sikap, kebiasaan, pemahaman, keterampilan, daya pikir, dan kemampuan lain (Hakim, 2005). Belajar adalah proses yang dialami seseorang seseorang ditandai dengan adanya perubahan dalam dirinya. Mahasiswa dalam menempuh pendidikannya di prodi pendidikan matematika juga belajar untuk memperlengkapi kompetensinya sebagai guru nantinya. Sehingga selama mahasiswa dalam perkuliahan perlu dibekali dengan kompetensi professional matematika. Sehingga perlu menggali bagaimana pemahaman mereka terhadap pengalaman belajar terkhusus mata kuliah yang membutuhkan pengetahuan matematika kompleks seperti Aljabar abstrak. Meskipun mata kuliah ini tidak secara langsung materinya sama dengan yang akan diajarkan nantinya pada saat mereka menjadi guru, namun materi ini tentunya menjadi dasar yang membangun kerangka berpikir 
mereka dalam belajar maupun mengajar matematika. Sehingga peneliti tertarik untuk menggali lebih dalam bagaimana mahasiswa memahami kompetensi apa saja yang dikembangkan dalam diri mereka selama perkuliahan aljabar abstrak, dan bagaimana mereka memahami relevansi antara mata kuliah aljabar abstrak terhadap persiapan kemampuan professional mereka nantinya.

Mata pelajaran matematika bertujuan agar peserta didik memiliki kemampuan sebagai berikut. 1) Memahami konsep matematika, menjelaskan keterkaitan antar konsep dan mengaplikasikan konsep atau algoritma, secara luwes, akurat, efisien, dan tepat, dalam pemecahan masalah; 2) Menggunakan penalaran pada pola dan sifat, melakukan manipulasi matematika dalam membuat generalisasi, menyusun bukti, atau menjelaskan gagasan dan pernyataan matematika; 3) Memecahkan masalah yang meliputi kemampuan memahami masalah, merancang model matematika, menyelesaikan model dan menafsirkan solusi yang diperoleh; 4) Mengomunikasikan gagasan dengan simbol, tabel, diagram, atau media lain untuk memperjelas keadaan atau masalah; 5) Memiliki sikap menghargai kegunaan matematika dalam kehidupan, yaitu memiliki rasa ingin tahu, perhatian, dan minat dalam mempelajari matematika, serta sikap ulet dan percaya diri dalam pemecahan masalah. Matematika merupakan ilmu universal yang mendasari perkembangan teknologi modern, mempunyai peran penting dalam berbagai disiplin dan memajukan daya pikir manusia. Perkembangan pesat di bidang teknologi informasi dan komunikasi dewasa ini dilandasi oleh perkembangan matematika di bidang teori bilangan, aljabar, analisis, teori peluang dan matematika diskrit. Untuk menguasai dan mencipta teknologi di masa depan diperlukan penguasaan matematika yang kuat sejak dini (Depdiknas, 2006). Setelah mempelajari matematika diharapkan mahasiswa mendapatkan beberapa kompetensi matematika yang perlu dari setiap pengalaman belajar matematik.

Mata kuliah Aljabar abstrak merupakan mata kuliah wajib pada mahasiswa prodi pendidikan matematika FIP (Fakultas Ilmu Pendidikan) Universitas Pelita Harapan (UPH). Mata kuliah ini perlu diajarkan pada mahasiswa pendidikan matematika. Mata kuliah ini membahas 3 konsep dasar yaitu Group, Ring dan Fields dilihat dari struktur dalam definisi operasi biner. Perkuliahan yang baik adalah perkuliahan yang membantu setiap mahasiswa dalam setiap tahap perolehan pengetahuannya, sehingga pendidik perlu tahu bagaimana para peserta didik belajar (ZAFFAR, 2009). Namun kesulitan dalam pembelajaran matematika ditemui dalam setiap jenjang pendidikan tanpa terkecuali pada mahasiswa (Kereh, 2013). Aljabar abstrak yang merupakan mata kuliah di prodi pendidikan matematika dimana mahasiswa banyak menemukan kesulitan dalam mempelajari, memahami dan menghargainya (Fortes, 2016). Nurlaelah (2009) juga mengatakan bahwa mata kuliah aljabar abstrak memuat konsep-konsep yang abstrak sehingga mahasiswa seringkali mendapatkan kesulitan dalam mempelajarinya.

Belajar mata kuliah aljabar abstrak membantu mahasiswa untuk meningkatkan kemampuan berpikir logis, analisis, sistematis, kritis, kreatif dalam menyelesaikan masalah. Mahasiswa juga diharapkan mengetahui dan memahami ide-ide abstrak dan gagasan kunci yang termuat dalam 
struktur aljabar. Mata kuliah ini memerlukan kemampuan berpikir logis dan bernalar yang lebih kompleks dibandingkan kemampuan berpikir yang diperlukan untuk mempelajari mata kuliah-mata kuliah matematika lain. Kompetensi tersebut diperlukan agar peserta didik dapat memiliki kemampuan memperoleh, mengelola, dan memanfaatkan informasi untuk bertahan hidup pada keadaan yang selalu berubah, tidak pasti, dan kompetitif. Selain itu Okur (2011) menyatakan bahwa kemampuan pemikiran dan kreatifitas yang abstrak menjadi prasyarat daya saing global industri teknologi di jaman sekarang. Untuk mencapai kompetensi berpikir logis yang diharapkan dalam mata kuliah ini perlu teknik untuk melatihnya agar terbentuk cara berpikir yang diperlukan dalam pemecahan masalah yang ada dalam mata kuliah ini.

Kompetensi adalah kemampuan bersikap, berpikir, dan bertindak secara konsisten sebagai perwujudan dari pengetahuan, sikap, dan keterampilan yang dimiliki oleh peserta didik (Depdiknas, 2006). Banyaknya konsep matematika yang abstrak dan rumit dalam mata kuliah ini serta dalam mempelajarinya membutuhkan aktivitas kognitif tingkat lanjut, dibutuhkan lebih banyak upaya mahasiswa dalam mempelajari konsep (Okur, 2011). Perlunya kompetensi analisis dalam mata kuliah ini serta kompleksitas berpikir logis yang dibutuhkan dalam mencapai kompetensi yang diharapkan dalam mata kuliah aljabar abstrak, sering mengakibatkan kesulitan dan kendala bagi mahasiswa pendidikan matematika FIP UPH. Kecenderungan untuk berpikir abstrak dan proses pembuktian logis yang masih kurang dikembangkan sampai tingkat SMA juga mengakibatkan mahasiswa kesulitan dalam belajar mata kuliah aljabar abstrak. Adanya anggapan bahwa mahasiswa adalah calon guru matematika di sekolah, sehingga mata kuliah aljabar abstrak kurang relevan dengan kompetensi guru nantinya membawa dampak kepada mahasiswa untuk tidak fokus pada kompetensi mata kuliah tersebut.

Dari pengalaman peneliti saat mewawancarai beberapa guru mentor yang merupakan alumni pendidikan matematika FIP UPH mengenai kompetensi matematika mahasiswa yang sedang mengikuti Program Pengalaman Lapangan, ada guru yang memberikan saran jika mahasiswa lebih baik dibekali konten matematika SMA, dengan mengurangi konten matematika kuliah yang berpikir tingkat tinggi seperti mata kuliah aljabar abstrak, analisis real, topologi dan lain sebagainya dengan alasan masih lebih membutuhkan konten SMA daripada konten tersebut ketika menjadi guru. Dengan adanya anggapan guru sebagai alumni yang berpendapat bahwa ketidakterkaitan antara mata kuliah aljabar abstrak dengan persiapan menjadi guru matematika di tingkat sekolah mendorong peneliti untuk menanamkan makna belajar kepada mahasiswa dengan meminta mahasiswa mengamati perkembangan berpikir selama pengalaman belajar aljabar abstrak. Calon guru sering menganggap bahwa belajar mata kuliah lanjutan pada perguruan tinggi tidak berguna bagi pengajaran mereka nantinya di sekolah (Wasserman, et all, 2017).

Penelitian ini bertujuan untuk menggali kompetensi apa saja yang dikembangkan selama perkuliahan aljabar abstrak bagi mahasiswa calon guru serta menggali bagaimana pemahaman mahasiswa calon guru terhadap pentingnya belajar aljabar abstrak. 


\section{METODE}

Penelitian ini menggunakan pendekatan deskriptif kualitatif. Pengambilan sampel pada penelitian ini dengan purposeful sampling. Peneliti mengumpulkan data melalui angket, wawancara, dokumen (refleksi) mahasiswa. (Creswell 2015). Setelah data dikumpulkan dilakukan validasi data dengan menggunakan triangulasi teknik, dimana mengecek kepada sumber yaitu mahasiswa dengan teknik berbeda. Data diperoleh melalui angket kemudian dicek dengan refleksi dan wawancara. Dari ketiga teknik diperoleh hasilnya data sama (Sugiyono, 2013). Adapun partisipan dalam penelitian ini adalah sebanyak 90 mahasiswa program studi Pendidikan Matematika UPH yang mengikuti mata kuliah aljabar abstrak pada semester genap tahun pelajaran 2017/2018.

\section{HASIL PENELITIAN}

\section{Kompetensi yang dikembangkan selama perkuliahan aljabar abstrak dari setiap pengalaman belajar mahasiswa.}

Untuk mengetahui kemampuan matematik yang dikembangkan selama perkuliahan aljabar abstrak data dikumpulkan melalui angket. Angket terdiri dari beberapa pilihan dan mahasiswa diberikan kebebasan untuk memilih bisa lebih dari satu pilihan. Hasil angket menunjukkan bahwa 79 dari 88 mahasiswa memilih bahwa analisis matematik mereka berkembang, sebanyak 65 mahasiswa setuju bahwa selama belajar Aljabar abstrak bahwa penalaran matematika mahasiswa berkembang, 63 mahasiswa setuju bahwa pemikiran logis mereka berkembang. Dari aspek kognitif Mahasiswa paling banyak setuju bahwa ketiga hal ini meningkat dalam dirinya. Dari aspek afektif mahasiswa setuju bahwa dengan belajar Aljabar abstrak meningkatkan ketelitian mereka dalam belajar dimana sebanyak 56 mahasiswa setuju bahwa ketelitian mereka dikembangkan selama perkuliahan Aljabar abstrak. Sebanyak 34 mahasiswa menyatakan bahwa selama belajar aljabar abstrak kepercayaan diri mahasiswa akan matematika dikembangkan selama perkuliahan, 38 mahasiswa mengatakan bahwa dengan belajar aljabar abtrak meningkatkan keuletan mereka. Berikut adalah data hasil Angket mahasiswa:

\section{KOMPETENSI YANG DIKEMBANGKAN SELAMA PERKULIAHAN ALJABAR ABSTRAK}

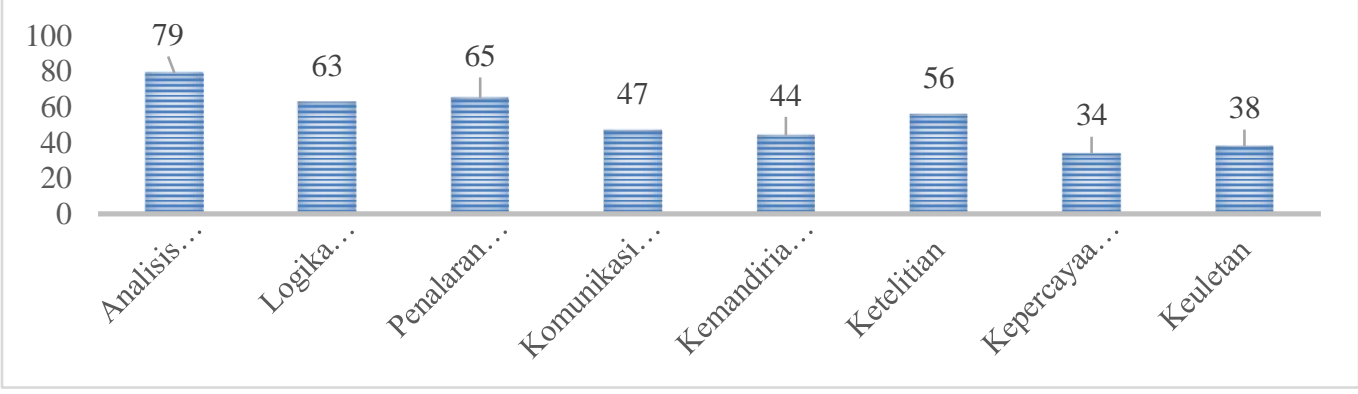

Diagram 1. Kompetensi yang dikembangkan selama perkuliahan Aljabar abstrak. 
Mahasiswa diberikan kesempatan untuk merefleksikan kompetensi matematik apa saja yang berkembang dalam diri mereka setelah mengikuti perkuliahan aljabar abstrak. Hasil refleksi mahasiswa menyatakan bahwa kemampuan yang berkembang dalam diri mahasiswa adalah sebagai berikut:

a. Ketelitian dan ketekunan. Dalam menganalisis dan mengerjakan soal dengan benar sangat perlu melatih ketelitian dan ketekunan. Mahasiswa juga belajar untuk mempertanggungjawabkan apa yang ada dalam perhitungan matematika yang telah dikerjakan.

b. Kemampuan berpikir secara logis, kritis, sistematis, serta berpikir kompleks. Kemampuan ini berkembang melalui materi yang membutuhkan pemikiran logis dan kompleks. Mahasiswa terlatih menyelesaikan masalah harus logis, kritis dan sistematis. Mahasiswa yakin bahwa dengan terlatihnya pemikiran secara logis, sistematis akan membentuk cara pikir mereka dalam menganalisa dan menyelesaikan setiap masalah dalam kehidupan.

c. Pemahaman konsep dasar matematika tingkat sekolah menengah misalnya tentang trigonometri dan aljabar, bilangan, himpunan, relasi serta fungsi, operasi bilangan, operasi biner dan lain sebagainya. Pemahaman akan konsep dasar matematika semakin diperdalam karena mahasiswa belajar definisi yang tepat pada konsep-konsep dalam matematika. Beberapa dasar matematika yang pernah dipelajari semakin dipertegas dan diperdalam kembali dalam belajar aljabar Abstrak.

d. Kemampuan pembuktian. Materi Aljabar abstrak pada umumnya membuktikan bukan hanya menghitung. Mahasiswa belajar untuk menemukan pembuktian yang tersusun dengan teratur dan terstruktur dan logis serta menguraikannya juga ke dalam kalimat matematik yang sistematis dan mudah dimengerti sehingga pembuktian dan penalaran matematika mahasiswa semakin meningkat.

e. Kemampuan komunikasi matematik. Mahasiswa belajar mengkomunikasikan pemikiran secara terstruktur melalui pembuktian, dimana setiap ide harus dituangkan dalam bahasa matematik, sesuai dengan aturan matematik. Kemampuan komunikasi matematika sangat dikembangkan melalui mata kuliah ini, meskipun beberapa mahasiswa menyatakan hal tersebut masih sulit.

f. Meningkatkan ketertarikan mahasiswa untuk fokus terhadap pemahaman konsep atau materi yang ada karena suatu saat sangat berguna untuk bahan mengajar di kelas. Ada mahasiswa yang merasa terberkati juga dengan belajar mata kuliah ini, karena dapat belajar dan memahami materi matematika yang abstrak serta dilatih untuk bertanggung jawab atas apa yang sudah diberikan Tuhan. Mahasiswa bahkan berinisiatif dan memiliki kesadaran bahwa untuk memperdalam materi diperlukan banyak membaca sumber lain dan berlatih.

g. Namun ada sebagian kecil mahasiswa yang belum menemukan penerapan mata kuliah aljabar abstrak dalam bidang apa, namun melalui mata kuliah tersebut, mahasiswa bisa membangun konsep- konsep fundamental matematika karena membangun suatu pemahaman dari definisi yang jelas tentang suatu konsep, sehingga kemampuan menganalisa semakin terlatih. 
Setelah melihat data angket data dikumpulkan melalui wawancara untuk melihat lebih detail tentang kompetensi yang bisa dikembangkan dalam belajar aljabar abstrak. kompetensi yang dikembangkan selama belajar aljabar abstrak antara lain:

a. Pembuktian matematik. Materi perkuliahan secara umum membutuhkan pembuktian, Melalui tahapan-tahapan dalam pembuktian dilatih untuk memberikan alasan logis yang membuat pernyataan itu benar. Sehingga lewat pembuktian, kemampuan berpikir kritis, logis dan terstruktur dikembangkan dalam belajar setiap materi didalam mata kuliah abstrak

b. Penguasaan akan materi matematika seperti himpunan, grup, teori bilangan, kalkulus, dan sebagainya. Melalui mata kuliah ini digali lebih mendalam lagi tentang definisi, teorema dalam konsep matematika demikian juga penjabaran aljabar dan operasi matematika. Melalui aljabar abstrak mahasiswa mendapatkan ilmu matematika yang tidak di pelajari di tingkat sekolah. Dimana tingkat sekolah terbiasa menggunakan rumus-rumus untuk mendapatkan hasil perhitungan namun pada mata kuliah ini lebih kompleks karena banyak pembuktian.

c. Komunikasi matematik. Selama belajar abstrak dilatih menuliskan jawaban dengan bahasa matematis, sistematis dan terstruktur untuk merumuskan ide-ide. Mahasiswa dilatih secara intens dengan pola berpikir yang logis, penyimbolan matematik, sistematis dalam menuangkan pemikiran dengan bahasa matematik. Mahasiswa belajar step by step pembuktian matematika yang harus logis.

d. Kemampuan bernalar dan analisa matematik. Mahasiswa terlatih dalam mengerjakan soal secara detail karena dalam mata kuliah ini harus benar-benar bernalar. Mahasiswa harus mampu memahami masalah yang diberikan soal, bukan sekedar menghitung namun dalam soal-soal yang diberikan dibutuhkan Analisa matematik yang dalam.

e. Ketelitian yang tinggi dalam melihat hal-hal yang sederhana. Melalui mata kuliah ini mahasiswa dituntut untuk lebih detail dan teliti. Ada mahasiswa yang sebelumnya menganggap remeh terhadap beberapa hal mudah dalam materi matematika, namun melalui pembelajaran membuat mereka lebih teliti.

f. Kreatifitas serta inovasi dalam mengerjakan soal. Kebanyakan soal membutuhkan ide bagaimana cara untuk menyelesaikannya dengan melakukan penjabaran atau modifikasi.

g. Ketekunan, karena mata kuliah ini membutuhkan kesabaran agar mampu menganalisis dengan benar.

h. Mengalahkan pikiran yang menganggap mata kuliah aljabar abstrak adalah sulit. Mahasiswa belajar untuk berusaha lebih dan menyukai sesuatu yang tidak disukai karena ada mahasiswa tidak suka aljabar abstrak dan menganggapnya suatu mata kuliah yang sulit, Namun mahasiswa lebih berusaha supaya dapat mengikuti mata kuliah tersebut dan memacu diri sehingga punya keinginan untuk belajar. Sosialisasi dengan teman sebaya juga semakin meningkat karena membutuhkan penjelasan ulang dari teman sebaya yang memahami mata kuliah ini jika ada yang tidak mengerti. 
i. Melalui penilaian dalam mengerjakan soal, kedisiplinan juga dilatih karena banyak simbol dan syarat-syarat yang harus dipenuhi. Jika ada salah satu rumus atau bagian yang kurang jika mengerjakan sebuah soal maka akan mempengaruhi penilaian. Mengerjakan soal butuh penalaran lebih dan harus memahami setiap teorema.

j. Bahasa Inggris. Ada mahasiswa merasa kompetensi Bahasa inggrisnya meningkat karena menggunakan text book. Mahasiswa berusaha memahami defenisi dan konsep lainnya dan harus melatih kemampuan terjemahan mereka. Namun, sering juga mahasiswa menjadi kebingungan.

k. Ada sebagian kecil mahasiswa yang tidak mengerti dan merasa tidak ada yang signifikan berkembang dari kompetensinya, karena tidak mengerti apa yang telah dipelajari.

\section{Pemahaman mahasiswa sebagai calon guru terhadap relevansi mata kuliah aljabar abstrak jika mereka mengajar nantinya di tingkat sekolah}

Penulis mengumpulkan data melalui angket untuk melihat relenvansi antara mata kuliah aljabar abstrak bagi calon guru. Sebanyak 88 mahasiswa ikut berpartisipasi dalam mengisi angket ini dan 86 mahasiswa $(97,73 \%)$ menyatakan bahwa belajar mata kuliah aljabar abstrak relevan dengan kebutuhan mahasiswa sebagai calon pendidik. Hasilnya digambarkan pada diagram batang berikut ini:

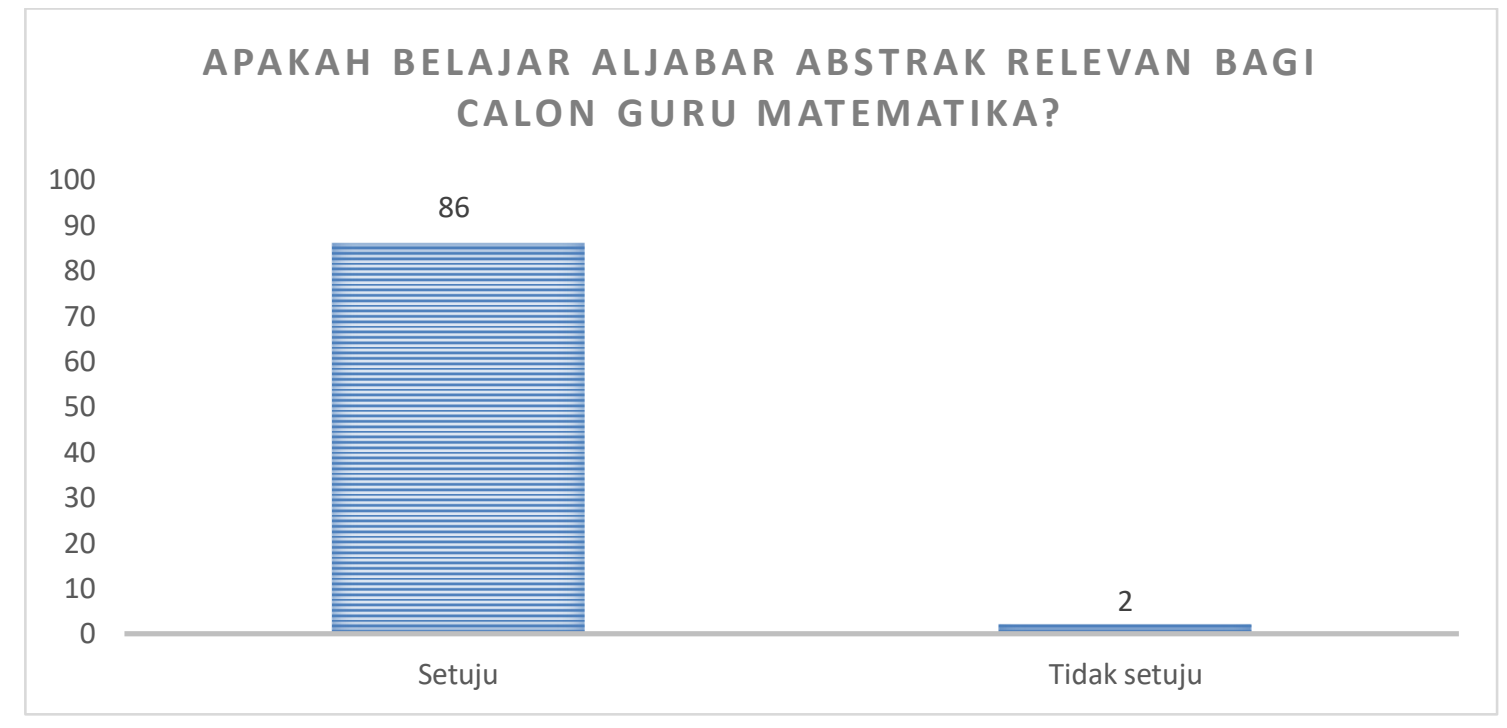

Diagram 2. Relevansi belajar Aljabar abstrak bagi calon guru

Angket yang diberikan kepada mahasiswa terdiri dari beberapa pilihan dan mahasiswa diberikan kebebasan untuk memilih bisa lebih dari satu pilihan. Diperoleh sebanyak 35 mahasiswa setuju bahwa belajar mata kuliah aljabar abstrak relevan bagi seorang guru SD, sedangkan 43 mahasiswa setuju bahwa calon guru perlu mempersiapkan diri sebagai guru matematika SMP melalui belajar mata kuliah aljabar abstrak. Sebanyak 62 mahasiswa setuju bahwa mata kuliah ini relevan untuk calon pendidik tingkat SMA, dan semua mahasiswa setuju bahwa mata kuliah ini relevan calon pendidik matematika tingkat kuliah khususnya di pendidikan matematika. Berikut adalah data hasil angket mahasiswa: 


\section{MATA KULIAH ALJABAR ABSTRAK RELEVAN TERHADAP KEBUTUHAN GURU TINGKAT?}

88

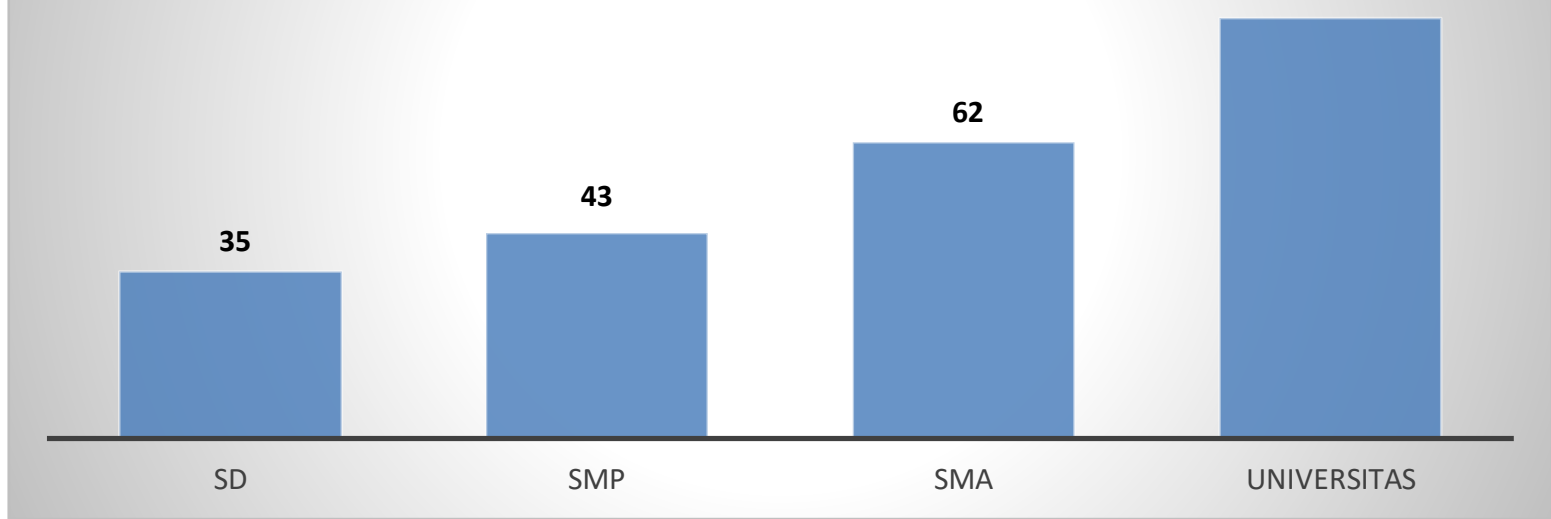

Diagram 3. Relevansi mata kuliah Aljabar abstrak terhadap guru/pendidik disetiap tingkatan para peserta didiknya

Data dikumpulkan melalui data refleksi dimana mahasiswa secara umum setuju bahwa aljabar abstrak melatih kompetensi matematika seorang guru matematika. Berikut hasil refleksi mahasiswa tentang perlu atau tidaknya calon guru belajar mata kuliah Aljabar abstrak:

a. Pengalaman belajar pada mata kuliah ini memberikan pengetahuan yang menyeluruh akan matematika dan konsep-konsep fundamental matematika yang sangat membantu untuk memecahkan permasalahan matematis.

b. Guru matematika perlu mendalami Aljabar abstrak sebagai dasar untuk memahami sebuah rumus dan konsep matematika lainnya. Di sisi lain, guru dapat membuktikan secara komprehensif mengapa rumus matematika itu ada dan memberi penjelasan yang logis dan kritis atau bahkan memberikan jalan pemecahan soal yang lebih masuk akal sehingga mudah dipahami oleh murid. Cenderung menekankan pada aspek kognitif dan mampu ditekankan pada konsep bilangan, himpunan, operasi biner, dan aljabar. Melalui perkuliahan ini juga mahasiswa melihat bahwa materi dalam matematika, semuanya saling berhubungan.

c. Guru matematika perlu memperkaya dirinya dengan berbagai kompetensi matematika supaya ketika menjadi guru nantinya dapat menjelaskan materi matematika dengan baik, jelas, sistematis dan logis kepada murid. Guru juga diharapkan dapat memberikan motivasi yang baik pada murid agar mereka bisa menyukai Matematika dan memahaminya dengan benar. Sehingga dapat mengembangkan pola pikir siswa yang kritis dan logis dalam memecahkan masalah matematika.

d. Dengan belajar Aljabar abstrak membuat mahasiswa dapat mengembangkan konsep-konsep matematika dan mempertajam wawasan mereka. Tidak hanya berbicara soal menghitung, akan tetapi juga belajar mencari solusi suatu masalah dan belajar untuk mengikuti langkah-langkah yang tepat dan sistematis. 
e. Kompetensi matematika yang didapatkan dalam kelas Aljabar Abstrak juga berguna untuk diterapkan dalam kelas pelatihan olimpiade siswa karena tentu soal yang dipecahkan bukan masalah rutin melainkan masalah yang membutuhkan logika dan pemecahan matematis yang kompleks yang dipelajari di kelas Aljabar abstrak.

f. Melalui pengalaman belajar mata kuliah ini membantu guru dan murid dalam melihat masalah matematika atau persoalan dari sudut pandang lain sehingga kekeliruan dapat terhindari serta berani untuk mengemukakan pendapat dengan diskusi dua arah dalam pembuktian.

g. Melalui pembelajaran Aljabar abstrak, mahasiswa akan mampu memperkenalkan Tuhan kepada siswa karena dapat mengenal-Nya melalui hal-hal yang telah disingkapkan-Nya, yaitu melalui penyelidikan, penemuan, pemikiran dalam matematika yang Tuhan berikan kepada manusia.

h. Mahasiswa juga mengerti sifat-sifat operasi aljabar dengan benar. Namun, ada beberapa mahasiswa yang menyatakan bahwa aljabar abstrak terlalu tinggi untuk dipelajari oleh siswa menengah atas.

Dari hasil wawancara mahasiswa, mereka setuju bahwa mata kuliah Aljabar abstrak relevan bagi mereka sebagai seorang pendidik di tingkat sekolah dikarenakan aljabar abstrak membentuk cara berpikir logis, meningkatkan kemampuan analisis matematika, membentuk cara bernalar secara matematis, membangun karakter lebih teliti, meningkatkan percaya diri akan kemampuan matematika, meningkatkan keuletan sebagai seorang pengajar dan mata kuliah ini berhubungan dengan materimateri matematika di tingkatan sekolah serta membantu mereka menyelesaikan masalah yang berhubungan dengan matematika di tingkat sekolah. Ada beberapa alasan yang mereka ungkapkan antara lain:

\section{Mata kuliah Aljabar abstrak perlu diajarkan untuk calon guru matematika SD dengan alasan:}

a. Menjadi dasar bagi mahasiswa sebagai calon guru untuk memahami dan menganalisis pelajaran sekolah sehingga bisa mengajar dengan pemahaman yang tepat. Anak SD juga perlu memahami dan ditanamkan konsep berlogika. Pemahaman akan mata kuliah ini penting untuk dapat menjelaskan matematika secara mendasar kepada anak SD terkhusus ketika ada siswa yang berpikir kritis.

b. Mata kuliah ini penting karena sebagai dasar dari konsep-konsep dasar matematika lainnya Misalnya menjelaskan dasar menghitung, penyimbolan, tata cara penulisan matematika yang benar. Apabila konsep yang diajarkan pada tingkat SD salah maka tingkat yang selanjutnya anakanak juga berpeluang yang besar untuk salah. Meskipun mungkin terlihat sederhana tetapi sangat mempengaruhi nantinya untuk materi di tingkat yang lebih tinggi.

c. Melalui pembelajaran aljabar abstrak, calon guru matematika dilatih untuk berpikir lebih kritis, sistematis, terstruktur, logiks. Karena itu guru sudah harus mengajarkan anak berpikir kritis atau membangun pemikiran anak sehingga tertata dengan baik. 
d. Untuk menambah wawasan konten, seorang guru harus memiliki pengetahuan yang lebih dibandingkan muridnya serta sebagai bahan untuk mempersiapkan siswa dalam olimpiade serta mempersiapkan masuk ke pendidikan yang lebih tinggi.

e. Membuat mahasiswa sebagai calon guru mengasah tingkat keuletan dalam memecahkan soal dan berpikir lebih teliti. Melalui pengalaman belajar aljabar abstrak, calon guru dapat mendorong siswa SD untuk belajar teliti dalam belajar matematika nantinya.

f. Dalam mengajar tingkat SD sering membutuhkan pengambilan keputusan segera dan tepat. Mata kuliah ini tidak hanya untuk di ruang kelas tapi juga berguna untuk melatih mengambil keputusan dalam masalah sehari-hari yang sering dihadapi.

\section{Mata kuliah Aljabar abstrak tidak perlu diajarkan untuk calon guru matematika SD dengan alasan:}

Karena materi matematika tingkat SD tidak memerlukan analisis yang tinggi. Materi yang dipelajari pada mata kuliah Aljabar abstrak tidak berkaitan langsung dengan materi matematika yang dipelajari di SD.

\section{Mata kuliah Aljabar abstrak perlu diajarkan untuk calon guru matematika SMP dengan alasan:}

a. Melalui pengalaman belajar Aljabar abstrak, mahasiswa dipersiapkan untuk dapat mengajar dan menjelaskan konsep dasar matematika dengan pemahaman yang tepat. Mata kuliah ini merupakan dasar dari mahasiswa sebagai calon guru memahami dan menganalisis mata kuliah lain, serta pelajaran matematika sekolah.

b. Beberapa materi Aljabar abstrak berkaitan dengan materi matematika SMP dan merupakan hasil pengembangan dari materi matematika SMP, misalnya himpunan. Materi matematika pada tingkat SMP juga sudah mulai kompleks dan analisisnya mulai rumit, sehingga dibutuhkan pemahaman yang lebih tinggi bagi seorang calon guru.

c. Perkembangan cara berpikir anak SMP sudah mulai menggunakan konsep berlogika dalam mata pelajaran matematika, sehingga diperlukan pemahaman dalam mata kuliah ini untuk membantu menjelaskan matematika kepada anak SMP.

d. Guru perlu membiasakan anak-anak SMP berpikir kritis untuk mempersiapkan siswa ke jenjang berikutnya. Untuk tingkatan siswa SMP sudah mulai berpikir kritis dalam belajar matematika.

e. Untuk membentuk dan membiasakan pola pikir kita dalam bermatematika, sehingga tidak merasa kesulitan dalam mengajar matematika dan menjadi sudah terbiasa dengan materimateri matematika. 
f. Pengalaman belajar selama perkuliahan Aljabar abstrak melatih kemampuan komunikasi matematik sehingga dapat menyederhanakan matematika. Banyak tata cara penulisan (penyimbolan) matematika yang harus dipahami.

g. Guru matematika SMP perlu mengembangkan ketelitian dalam dirinya.

h. Seorang guru matematika SMP seharusnya memiliki pengetahuan matematika yang luas. Seorang guru harus memiliki pengetahuan yang lebih dibandingkan muridnya, terkhusus ketika mempersiapkan siswa dalam perlombaan olimpiade.

i. Karena dengan mata kuliah ini mahasiswa dapat melihat pola matematika dan menyelesaikan soal secara lebih sistematis. Dalam pembelajaran Aljabar abstrak juga membentuk pola berpikir matematika serta melatih logika berpikir serta mengembangkan kemampuan bernalar mahasiswa.

\section{Mata kuliah Aljabar abstrak tidak perlu diajarkan untuk calon guru matematika SMP dengan alasan:}

Materi yang dipelajari dalam aljabar abstrak tidak semua berkaitan dengan materi matematika SMP. Materinya Aljabar abstrak juga terlalu rumit dan memusingkan. Serta masih sulit bagi anak SMP untuk mengembangkan pengetahuan kritis,

\section{Mata kuliah Aljabar abstrak perlu diajarkan untuk calon guru matematika SMA dengan alasan:}

1. Siswa SMA mulai berpikir logis, kritis dan analitis serta mengasah kemampuan logika, sehingga guru perlu mengarahkan anak untuk membiasakan berpikir tingkat tinggi.

2. Untuk membiasakan pola pikir mahasiswa tentang matematika, sehingga tidak merasa kesulitan dalam mengajar matematika dan menjadi sudah terbiasa dengan materi-materi matematika.

3. Karena mata kuliah Aljabar abstrak menjadi dasar dan landasan yang kuat dalam mengajar matematika tingkat SMA serta bahan pengetahuan untuk mengajar dalam kelas sehingga guru bisa memahami dan mengajarkan konsep matematika dengan benar. Melalui mata kuliah ini juga mahasiswa dipersiapkan untuk mengajar dengan pemahaman yang tepat dalam membantu menjelaskan kepada anak SMA sehingga mahasiswa calon guru dapat menjelaskan materi secara mendalam, dari mana munculnya pemikiran akan rumus yang sedang dipelajari dan juga memperjelas suatu materi yg abstrak.

4. Mata kuliah ini penting sebagai dasar dari konsep-konsep dasar matematika yg lainnya. Karena mata kuliah ini dasar dari mahasiswa memahami dan menganalisis mata kuliah lain, serta pelajaran sekolah. Materi-materi di SMA juga berkaitan dengan Aljabar abstrak seperti himpunan, fungsi, bilangan. Materinya juga sudah mulai memasuki tingkat yang rumit. 
5. Guru di SMA juga membutuhkan ketelitian dan kemampuan mengkomunikasikan ide-ide matematika kepada siswa, karena mahasiswa calon guru semakin belajar untuk teliti dan teratur serta terstruktur dalam penyelesaian soal.

6. Karena dapat membentuk karakter yang bertanggungjawab, tidak mudah menyerah dan berpikir kritis, sistematis.

7. Memperluas pengetahua. Ketika ada pertanyaan-pertanyaan dari siswa-siswi SMA yang membutuhkan jawaban yang lebih analitis serta seorang guru harus memiliki pengetahuan yang lebih dibandingkan muridnya. Juga membantu anak dalam olimpiade atau bahkan masuk kuliah. Guru harus lebih cepat menganalisis soal dan lebih teliti dan harus mengetahui konsep-konsep dari matematika.

8. Untuk menyusun pola berpikir logis, kritis dalam matematika. Sehingga guru dapat membangun pemikiran kritis dan logika yang baik pada anak SMA karena mereka akan menuju ke perkuliahan, untuk persiapan masuk ke dalam dunia luar yang lebih nyata.

9. Karena ada beberapa konsep dalam materi SMA yang membutuhkan penjelasan struktur Aljabar yang detail sehingga dibutuhkan analisis yang lebih dan konsep-konsep yang matang dalam mengajarkan matematika ke siswa SMA. Tingkat berpikir anak SMA sudah kritis dan keingintahuan akan asal usul segala sesuatu termasuk rumus matematika cukup tinggi.

10. Mempersiapkan mahasiswa untuk membantu siswa membuktikan dan mendalami pemahaman akan materi SMA.

11. Dengan materi yang semakin sulit, sangat diperlukan penguasaan materi yang banyak, pemahaman dalam hal dasar perhitungan matematika.

\section{Mata kuliah Aljabar abstrak tidak perlu diajarkan untuk calon guru matematika SMA dengan alasan:}

1. Karena di SMA tidak mempelajari materi Aljabar abstrak, sehingga bisa berdampak memusingkan.

\section{PEMBAHASAN}

Setelah melihat hasil angket, refleksi dan wawancara mahasiswa mahasiswa calon guru sangat membutuhkan perkuliahan Aljabar abstrak. Karena selama perkuliahan dilatih dan dikembangkan kompetensi matematika dalam diri mahasiswa. Kompetensi tersebut diatas disadari oleh mahasiswa berkembang karena kompetensi tersebut belum ada sebelumnya. Materinya dalam mata kuliah ini secara umum abstrak dan merupakan materi dalam matematika yang tidak diaplikasikan secara langsung dalam kehidupan sehari-hari seperti kebanyakan materi matematika tingkat sekolah lainnya yang banyak pengaplikasiaannya dalam kehidupan sehari-hari. Namun ditengah kesulitan dalam memahami materi tersebut kompetensi matematik dilatih dan kompetensi tersebut berkembang dalam diri mahasiswa. 
Melalui angket ada 2 mahasiswa yang tidak setuju bahwa mata kuliah ini tidak relevan dengan kebutuhan sebagai calon pendidik, namun mereka setuju bahwa mata kuliah ini membangun kemandirian untuk mengembangkan pemahaman yang lebih tinggi. Ketidaksetujuan tersebut didasarkan karena siswa di sekolah tidak mempelajari materi yang dipelajari dalam mata kuliah aljabar abstrak, sehingga lebih relevan bagi calon dosen. Mahasiswa tersebut merasa kesulitan dalam memahami materi karena keterbatasan dalam mempelajari buku utama yang berbahasa inggris serta penjelasan dosen terlalu cepat.

Selain kompetensi matematis, ada aspek sikap yang dikembangkan melalui perkuliahan ini yaitu sikap keuletan, ketelitian, tanggung jawab dan sikap tidak mudah menyerah. Perkuliahan ini membawa dampak yang baik bagi mahasiswa. Dari hasil angket terlihat, mahasiswa paling banyak yang menyatakan aspek ketelian dan keuletan ditingkatkan dalam mata kuliah ini. Karena mahasiswa dilatih untuk detail dalam memahami konsep dan dibutuhkan tingkat akurasi yang tinggi dalam proses penilaian.

Dari seluruh jawaban mahasiswa yang mengikuti kelas Aljabar abstrak ini, ada suatu hal yang lebih sering disebutkan tentang relevansi di mana mata kuliah ini memberikan pengetahuan yang menyeluruh akan matematika dan tentunya konsep-konsep fundamental yang sangat membantu untuk memecahkan permasalahan matematis. Meskipun tidak semua mahasiswa setuju mata kuliah ini relevan bagi guru SD dan SMP, namun secara umum mahasiswa menyebutkan melalui mata kuliah ini pola pikir matematis berkembang dalam diri mahasiswa dan merupakan modal dasar bagi calon guru untuk memahami matematika secara fundamental. Mahasiswa belajar banyak hal dalam kelas Aljabar abstrak dan memperlengkapi mereka berbagai kompetensi matematik.

Semua kompetensi matematik yang dikembangkan serta aspek afektif yang dikembangkan menjadi modal dasar bagi seorang guru matematika dan semuanya akan berpengaruh pada pengajaran mereka nantinya. Bagaimana mahasiswa guru melalui setiap kesulitan dalam memelajarinya namun mereka mendapatkan bahwa diri mereka terlatih dan sikap tidak mudah menyerah dikembangkan dalam diri mereka. Hasil penelitian ini sesuai dengan pendapat Wasserman (2016) bahwa seorang guru dengan pengetahuan Aljabar abstrak yang berkembang dapat mengubah cara mengajar guru matematika. Penguasaan akan aljabar abstrak akan berpengaruh pada penguasaan pengajaran aljabar sekolah.

Dosen memiliki pengaruh dalam membentuk keyakinan mahasiswa terhadap matematika dalam kelas kuliah, meskipun mahasiswa datang dengan berbagai keyakinan dan pendekatan pembelajaran. Diharapkan dosen dapat membantu mahasiswa untuk terlibat aktif dan mendalam untuk mengembangkan pemahaman mereka mengenai konsep abstrak dan meningkatkan kemampuan mereka dalam membangun bukti (Alcock, 2015). Sikap mahasiswa terhadap matematika dalam kelas Aljabar abstrak dibangun melalui arahan dosen untuk tetap meresponi setiap kesulitan dengan benar. Melalui pemecahan masalah, kemampuan pembuktian terbentuk cara berpikir dan sikap tidak menyerah terhadap matematika. Melewati setiap proses berpikir dengan memaksimalkan kapasitas 
berpikir akan membentuk daya pikir dan daya saing mahasiswa. Dosen membantu mahasiswa untuk melihat bahwa ada perkembangan daya pikir matematik maupun sikap melalui setiap tahapan perkuliahan serta membangun kepercayaan diri dalam mahasiswa dengan memberi apresiasi dalam setiap perkembangan mereka dalam perkuliahan.

Kemampuan setiap mahasiswa dalam matematika berbeda-beda sehingga kesiapan mahasiswa dalam materi pembelajaran baru juga berbeda. Sedangkan keterampilan berpikir matematis dalam memecahkan masalah membutuhkan pemahaman konsep yang memadai terkait dengan masalah yang dipecahkan (Rochmad, 2018). Ketidakmampuan mahasiswa dalam menghubungkan antar konsep dan memecahkan masalah akan membuat mahasiswa sulit berpikir kritis serta mengikis kepercayaan diri mereka akan kemampuan matematiknya. Hal inilah yang menjadi penyebab mahasiswa tidak mampu mengatasi setiap kesulitan mereka dan berdampak pada hasil belajarnya. Dosen senantiasa memotivasi mereka dengan menanamkan konsep bahwa setiap mahasiswa mengalami kesulitan dalam belajar namun, sikap dalam menghadapi kesulitan itulah yang membedakan hasil yang mereka capai. Rendahnya motivasi belajar matematik siswa menjadi penyebab masalah-masalah literasi dan sikap matematika (Hendriana, 2014). Dengan motivasi dan apresiasi dosen terhadap setiap proses belajar mahasiswa membentuk sikap positif dalam diri mahasiswa, sehingga mereka dapat menghargai setiap perkembangan belajar mahasiswa.

\section{KESIMPULAN}

Pengalaman belajar mahasiswa dalam belajar aljabar abstrak membawa dampak yang signifikan bagi perkembangan kompetensi matematik mahasiswa. Meskipun banyak materi kuliah yang dipelajari tidak semua materi yang akan diajarkan dalam materi sekolah, namun para calon mahasiswa sebagai calon guru sepakat bahwa melalui pengalaman belajar mereka, mereka dipersiapkan menjadi guru matematika yang menguasai konten guru matematika. Mahasiswa setuju bahwa mata kuliah Aljabar abstrak relevan bagi mereka sebagai seorang pendidik di tingkat sekolah dikarenakan dengan belajar aljabar abstrak membuat mahasiswa dapat mengembangkan kompetensi dan konsep-konsep matematika. Tidak hanya berbicara soal menghitung angka, akan tetapi juga belajar mencari solusi suatu masalah dan belajar untuk mengikuti langkah-langkah yang tepat dan sesuai. Hal ini menunjukkan bahwa mata kuliah tersebut sangat dibutuhkan oleh seorang calon guru matematika atau dengan kata lain, mata kuliah ini perlu diberikan kepada mahasiswa sebagai calon guru.

Kompetensi yang dikembangkan selama perkuliahan aljabar abstrak dari setiap pengalaman belajar mahasiswa adalah kemampuan analisis matematika, berpikir logis atau kritis, bernalar secara matematis, mengkomunikasikan ide-ide matematik, bagaimana membuat sebuah pembuktian secara teratur dan berurutan, melatih pola pikir yang sistematis dalam menjawab soal baik dalam 
menganalisis soal, mengerjakan soal secara sistematis, kemandirian mengembangkan pemahaman yang lebih tinggi, ketelitian, percaya diri akan kemampuan matematika dan keuletan.

\section{DAFTAR PUSTAKA}

Alcock. L, Brown. G, Dunning. C. (2015). Independent Study Workbooks for Proofs in Group Theory. International Journal of Research in Undergraduate Mathematics Education. 1(1), pp 3-26

Creswell. (2015). Riset Pendidikan Perencanaan Pelaksanaan, dan Evaluasi Riset Kualitatif \& Kuantitatif, Edisi ke-5. Yogyakarta: Pustaka Pelajar.

Depdiknas. (2005). Undang-Undang Nomor 14 Tahun 2005, Tentang Guru dan Dosen, Jakarta: Depdiknas.

Depdiknas. (2006). Permendiknas No 22 Tahun 2006 Tentang Standar Isi. Jakarta : Depdiknas.

Fortes, E. (2016). Teaching Abstract Algebra Online. The Normal Lights, 10(1), 154 - 181.

Hakim, Thursan, (2005). Belajar secara efektif : panduan menemukan teknik belajar, memilih jurusan, dan menentukan cita-cita. Jakarta: Puspa Swara.

Hendriana, Heris. (2014). Membangun Kepercayaan diri Siswa Melalui Pembelajaran Matematika Humanis. Jurnal Pengajaran MIPA, 19(1). 52-60.

Kereh, C, T., Sabadar, J., \& Tjiang, P. C. (2013). Identifikasi Kesulitan Belajar Mahasiswa dalam Konten Matematika pada Materi Pendahuluan Fisika Inti. Proceedings of Seminar Nasional Sains dan Pendidikan sains. Fakultas sains dan Matematika, UKSW.

Naim, N. (2011). Menjadi Guru Inspiratif. Yogyakarta: Pustaka Pelajar

Nurlaelah, E. dkk. (2009). Pembelajaran Mata Kuliah Struktur Aljabar Yang Berbasis Komputer Dan Tugas Terstruktur Untuk Menggali Potensi Kreatif Dan Daya Matematik Mahasiswa. Dipresentasikan dalam Seminar Nasional Aljabar, Pengajaran Dan Terapannya, Jurusan Pendidikan Matematika FMIPA UNY Yogyakarta.

Okur. M, Dikici. R, Sanalan. V, Tatar. E. (2011). Computer Applications in Teaching Abstract Algebra. International Journal of Applied Science and Technology. 1(1), 20-27.

Reys, E. R., Suydam, M. N., \& Lindquist, M. M. (2014). Helping children learn mathematics $\left(11^{\text {th }}\right.$ ed.). Needham Heights, MA: Allyn \& Bacon.

Rochmad, Kharis. M, Agoestanto. A, Zahid. M. (2018). Misconception as a critical and creative thinking inhibitor for mathematics education students. Unnes Journal of Mathematics Education. 7(1). https://doi.org/10.15294/ujme.v7i1.18078

Sugiyono. (2013). Metode Penelitian Pendidikan: Pendekatan Kuantitatif, Kualitatif, dan R\&D. Bandung: Alfabeta.

Wasserman, N. H, (2016). Abstract Algebra for Algebra Teaching: Influencing School Mathematics Instruction. Canadian Journal of Science, Mathematics and Technology Education. 16(1). https://doi.org/10.1080/14926156.2015.1093200 
Wasserman, N. H, et all. (2017). Making Real Analysis Relevant to Secondary Teachers: Building Up from and Stepping Down to Practice. Problems, Resources, and Issues in Mathematics Undergraduate Studies. 27(6). https://doi.org/10.1080/10511970.2016.1225874

Zaffar. A, Quraishi.S. M, Ansari. M.R. (2009). Teaching of Abstract Algebra at Undergraduate Level. The Sindh University Journal of Education. 39(10). 1-12 